ROCZNIKI HUMANISTYCZNE

Volume 66, issue $2-2018$

SELECTED PAPERS IN ENGLISH

DOI: http://dx.doi.org/10.18290/rh.2018.66.2-2se

BOGUMIE SZADY

\title{
THE FALL OF THE CHORUPNIK PARISH. A CONTRIBUTION TO THE HISTORY OF THE REFORMATION IN POLAND
}

The fall and dissolution of the Latin Catholic parish in Chorupnik lies within the context of social and religious relations present during the period of the Reformation and Counter-Reformation. An in-depth and multi-layered interpretation of historical sources showing the fortunes of individual churches in this turbulent time may clarify the reasons for the development and then the retreat of the Reformation forces in the local perspective. Analysis of the fate of this parish, both in the institutional (with respect to ecclesiastical law) and socio-religious contexts, where the interests of the local Church and church owners intertwined, is crucial for understanding the mechanisms of the nobility transitioning en masse to reformed denominations, and then returning to the Catholic Church.

The history of the Chorupnik parish, located in the area of the former diocese of Chełm (near Gorzków, Lublin Province), is of interest to us also because the most important studies devoted to the history of parishes in the diocese of Chełm offer disparate information about its character and functioning. This parish is mentioned several times by A. Wadowski in his unpublished materials devoted to the history of the diocese. ${ }^{1}$ They are passed over by W. Czarnecki, who dealt with the development of the network of Latin Church parishes in Chełm land until the early $17^{\text {th }}$ century, and L. Bieńkowski,

Dr Hab. Bogumit SzADY, an associate professor of the John Paul II Catholic University of Lublin (KUL), head of the Department of Early Modern History, Institute of History of KUL; email: szady@kul.lublin.pl

The Polish version of the article was published in Roczniki Humanistyczne vol. 61, issue 2 (2013).

${ }^{1}$ Jan Ambroży WADOwsKi, Dzieje dawnej diecezji chetmskiej i jej kościołów, BPANKr, MS no. 2372, k. $18 \mathrm{v}, 51 \mathrm{v}$. 
who examined the development of the diocese until the mid- $15^{\text {th }}$ century. ${ }^{2}$ No major doubts are raised by the very existence of a church in the village of Chorupnik, whereas its erection, character and history in the $16^{\text {th }}$ century are attested only indirectly by odd mentions from the $17^{\text {th }}$ and $18^{\text {th }}$ centuries.

The exact date when the church in Chorupnik was established is unknown. The village itself appears in historical sources at the beginning of the $15^{\text {th }}$ century, on the occasion of the demarcation of the estates of Gorzków and Poperczyn in $1406 .{ }^{3}$ Czarnecki, who studied the settlement in Chełm land during the $15^{\text {th }}$ and $16^{\text {th }}$ centuries, assigned the village to the parish of Gorzków ${ }^{4}$ or Żółkiewka. ${ }^{5}$ The parish in Chorupnik is mentioned for the first time in the minutes of the commission assembled on $17^{\text {th }}$ January 1623 (taken in Kumów on $18^{\text {th }}$ January), called into existence by bishop Maciej Łubieński in order to renew the parish in Gorzków (the original parish documents perished). Apart from determining the remuneration, the house for the parish priest and the parish district, the commission noted that in the village of Chorupnik "se aliquando ecclesiam parochialem constructam vidisse, cuius parietes post eiusdem desolationem illustrissimus dominus palatinus olim Lublinensis sustulerat stabulumque ex eisdem construi fecerat." " A day after the commission (18 $8^{\text {th }}$ January 1623), Stanisław Skrzyński (Skrzynno), the vicar of the Lublin collegiate church appeared before the church official. ${ }^{7} \mathrm{He}$ received presentation for the parish in Gorzków, issued by Stanisław Gorzkowski, the heir in Gorzków, Czysta Dębina, Olchowiec and Wielkopole. ${ }^{8}$ Already a week later $\left(25^{\text {th }}\right.$ January) he received canonical institution for this

\footnotetext{
${ }^{2}$ Ludomir BIEŃKOwSKI, “Działalność organizacyjna biskupa Jana Biskupca w diecezji chełmskiej (1417-1452)," Roczniki Humanistyczne 7, no. 2 (1958): 187-256. Włodzimierz CzARNECKI, "Rozwój sieci parafialnej Kościoła łacińskiego w ziemi chełmskiej do początku XVII wieku," Roczniki Humanistyczne 48, no. 2 (2000): 29-89.

${ }^{3}$ Stanisław KURAŚ and Irena SUŁKOWSKA-KURASIOwA, editors, Zbiór dokumentów małopolskich, part 6, no. 1698 (Wrocław: Zakład Narodowy im. Ossolińskich-Wydawnictwo Polskiej Akademii Nauk, 1974), 263.

${ }^{4}$ Włodzimierz CZARNECKI, "Sieć osadnicza ziemi chełmskiej od połowy XIV do połowy XV wieku," Rocznik Chetmski 3 (1997): 51. Chorupnik is assigned to the parish of Gorzkow in the tax register from 1564, see Ziemie ruskie. Ruś Czerwona, edited by Aleksander JABŁONOWSKI (Warszawa, 1902), 195. Vol. 7, part 1 of Polska XVI wieku pod względem geograficzno-statystycznym. Źródła dziejowe 18/1.

${ }^{5}$ Włodzimierz CZARNECKI, "Rozwój sieci parafialnej," 84.

${ }^{6}$ The quoted fragment refers to Marek Sobieski, the voivode of Lublin and owner of Chorupnik, available at the Archdiocesan Archive in Lublin (hereafter AAL), Rep60 A154, sheet 551.

${ }^{7}$ Stanislaw Skrzynski (Skrzynno) had been presented earlier in 1619 and installed in the parish in Chodywańce, AAL, Rep60 A107, sheets 140v, 147.

${ }^{8}$ AAL, Rep60 A154, sheet 47.
} 
parish. ${ }^{9}$ Quite soon, reverend Skrzyński came into conflict with Stanisław Gorzkowski, who would not implement the provisions of the foundation, in particular one concerning the transfer of two tans of land to the parish. ${ }^{10}$ The conflict between the patron and the Gorzków parish priest was swelling and probably led to the removal of Skrzyński from the parish. ${ }^{11}$

There is no direct evidence concerning the fate of the Chorupnik church during the Reformation period. It was not until the middle of the $17^{\text {th }}$ century that the issue of the parish emerges a little more fully in sources when attempts are made to merge it with the parish in Gorzków, regained from the hands of Protestants. On $22^{\text {th }}$ December 1639, bishop Remigiusz Koniecpolski granted pastor Marek Rybułkowicz permission to join the parish in Chorupnik to his parish. This is mentioned in the visitation record of $21^{\text {th }}$ August 1726 , but it does not quote the text of the document itself, which was recorded in the consistory files on $20^{\text {th }}$ May $1643 .{ }^{12}$ The fate of the original document of the incorportaion of the Chorupnik parish in the parish of Gorzków must have been turbulent, since it was only in the visitation records of the Krasnystaw decanate from 1803 that its copy was found, in which it was emphasized that the document had been destroyed. The copy contains many gaps - the transcriber used dots for ellipsis in places where words and fragments were missing.

At this point, a question should be asked about the reasons for granting permission for the incorporation of the Chorupnik parish. This is an important issue in the light of further events connected with the process of transferring the remuneration of the parish in Chorupnik to the Gorzków parish priest. Although the header of the visitation record is entitled "Incorporatio ecclesiae Chorupnicensis ad ecclesiam Gorzkoviensem," its a strict legal definition implies it was a union of benefices ("unio beneficiorum"). Incorporation as a phenomenon appears in the late Middle Ages and was interpreted by the canonists as a special case of unio beneficiorum-usually consisted in incorporating a benefice into another collegial body (e.g. a monastery, cathedral chapter, or college of collegiate vicars). ${ }^{13}$

\footnotetext{
${ }^{9}$ AAL, Rep60 A154, sheet 552v.

${ }^{10}$ AAL, Rep60 A109, sheets 29v-32.

${ }^{11}$ AAL, Rep60 A109, sheets 40v-41v. A person with an identical name and family name then appears in sources as an altarist in Dubienka and temporary parish administrator (commendarius) in Tyszowce, see AAL, Rep60 A110, sheets 136, 141, 175, 184.

${ }_{12}$ AAL, Rep60 A154, sheet 45.

${ }^{13}$ Justus Richard FOESSER, De unione, speciatim de incorporatione beneficiorum (Mainz, 1869), 13-16; Franciszek BĄсZKowicz, Prawo kanoniczne, vol. 1 (Opole: Wydawnictwo Diecezjalne Św. Krzyża, 1957), 345-47.
} 
The joining of beneficiaries and incorporations should take place for an obvious reason and for the benefit of the Church (causa iusta, "iusta causa uniendi beneficia est Ecclesiae necessitas vel ipsius utilitas"). One of these reasons was considered to be commonly insufficient remuneration of the benefice to which another benefice was joined. The basis for the incorporation could also be the destruction of the church or a small number of the faithful combined with a short distance between churches. ${ }^{14}$ Regardless of which legal interpretation we adopt (incorporation or union), since the church was destroyed, its revenue taken over by the owners of the village, and because of the nearness of the parish in Gorzków, the parish in Chorupnik satisfied the conditions for incorporation. It is difficult to assign the incorporation of the Chorupnik parish into the parish in Gorzków to one of the categories provided for by law. In any case, the relations between these benefices were dealt with by committees called in the 1640s. The content of the incorporation document itself points rather to pleno iure incorporation (quoad temporalia et spiritualia), which caused the subordination of property and the faithful of the Chorupnik parish to the Gorzków parish priest (unio subiectiva et accessoria). ${ }^{15}$

The need to obtain consent of the benefice patrons to incorporation or union is a problematic issue under canon law. However, the controversy concerns only ecclesiastical patronage, since in the case of secular patronage, the provisions of law quite explicitly provided for the necessity of patrons' consent. ${ }^{16}$ In this context, the document issued by bishop Koniecpolski did not fully meet the norms of canon law as it lacked information regarding the consent of the patrons of the parish in Chorupnik (Sobieski). Analysed in another article, ${ }^{17}$ the document of incorporation of the parish in Grabowiec

\footnotetext{
${ }^{14}$ Lucius FERRARIS, Prompta bibliotheca canonica, iuridica, moralis, theologica, nec non ascetica, polemica, rubricistica, historica, vol. 9 (Venice, 1782), 292-93.

15 “.... ad ecclesiam parochialem in Gorzkow tam in spiritualibus quam in corporalibus dependeat et a rectore moderno Gorzkoviense et eius successoribus gubernetur" (AAL, Rep60 A 191, sheet 66v). Thorough reading of the legislation permits an observation that the classification of unions of benefices (unio beneficiorum) defines relations between benefices (per confusionemexstinctiva, per subiectionem-accessoria, per aequalitatem-aeque principalis), while the types of incorporation refer more to the material scope (quoad temporalia-minus pleno iure, quoad temporalia et spiritualia — pleno iure), see Justus Richard FOESSER, De unione, 12-15.

${ }^{16}$ Lucius FERrARIS, Prompta bibliotheca, vol. 9, 293.

17 Bogumił SZADY, "Inkorporacja parafii w Grabowcu do chełmskiej kapituły katedralnej w 1624 roku," in Kościót. Społeczeństwo. Kultura. Prace ofiarowane Profesorowi Wiestawowi Müllerowi z okazji pięćdziesięciolecia pracy naukowej i dydaktycznej, edited by Janusz Drob et al. (Lublin: Werset, 2004), 133-45.
} 
into the cathedral chapter in Krasnystaw in 1624 contained a very explicit consent of the parish's patron (a separate royal document). Probably, there was no such consent on the part of Jakub Sobieski at all. The document issued by bishop Koniecpolski addressed the need to recover the documents testifying to the revenue of the parish in Chorupnik. ${ }^{18}$ The bishop, by joining the parish in Chorupnik to the parish in Gorzków, made the parish priest in charge of regaining the revenue lost by the parish in Chorupnik. In this way, he created a legal circumstance enabling the procedures which were utilized by Marek Rybułkowicz, the parish priest of Gorzków He tried to recover his former revenue and documents of the parish in Chorupnik before the Krasnystaw land court, bringing a case against Jakub Sobieski and his mother and Marek Sobieski's widow, Katarzyna née Tęczyński, the owners of Chorupnik and some some part of Gorzków.

The content of the litigation documentation implies that it was important to determine the fate of the church and the Chorupnik parish, the circumstances in which the temple was dismantled and its property taken over. The statement of claim contained information that it was Marek Sobieski, voivode of Lublin, who dissolved the church in Chorupnik and took possession of its revenue and the subjects. ${ }^{19}$ This is the most likely situation, considering Marek Sobieski's strong relations with Calvinism in the region of Lesser Poland. Apparently, he returned to Catholicism around 1598-according to H. Gmiterek, it was prerequisite for taking up the office of the Lublin voivode. ${ }^{20}$

The visitation books of the Gorzków parish (1758) mention a commission that met on $3^{\text {rd }}$ November 1645 at the church cemetery in Chorupnik. It was attended by Valentine Turoboyski, the custodian of the Krasnystaw cathedral, Jan Sasin, the official general of Chełm, Krzysztof Stoiński, the starost of Krasnystaw, and Marek Zwiartowski. The original minutes from this

\footnotetext{
18 “[...] sed et literas fundationis eius recuperandi” (AAL, Rep60 A 191, sheet 66v).

19 "Quia quemadmodum olim illustris et magnificus Marcus Sobieski, palatinus Lublinensis, parens et maritus ipsorum, ecclesiam parochialem catholicam in villa Chorupnik sitam ad ecclesiam parochialem Gorzkoviensem uti matrem antiquitus pertinentem, for antecessores and possessores villae Chorupnik extructam, apparamentis ecclesiasticis et dote sufficienti ornatam, privata autoritate sua sustulerat, apparamenta et fundos, agros, sylvas, mericas, prata, hortos subditosque ecclesiasticos nolenter $[s]$ occupaverat" (AAL, Rep601 A154, sheet 553v). The term "sustulerat" should be translated as the dismantling of a church, not merely robbing it (a few lines below the phrase appears: "ecclesiam eandem-deportatam").

${ }^{20}$ See Henryk GMiterek, "Sobieski Marek h. Janina," in Polski Stownik Biograficzny, vol. $39,503$.
} 
commission were destroyed during the Cossack wars in 1648. Its copy was confirmed in the municipal files of Krasnystaw on $18^{\text {th }}$ April 1654 at the request of Mikołaj Rudnicki, the representative of the Sobieski family, the owners of Chorupnik and some inhabitants of Gorzków. It furnishes additional data about the history of the church in Chorupnik. It turns out that Chorupnik was acquired in the $16^{\text {th }}$ century by Marek Sobieski from Eustachy Romanowski. The church would have been devastated by then. ${ }^{21}$ Czarnecki characterises the Romanowski family as "immigrant Polish nobility, who arrived and settled in the poviat of Krasnystaw."22 Connections of the Romanowski family, Bończa coat of arms, with the Reformation movement are little known. Perhaps it is Eustachy Romanowski who is mentioned as a participant in the funeral of Jakub Bitinius, a minister from Lubartów and a con-senior of the Lublin district, taking place in Krasnystaw in $1582 .{ }^{23}$

The findings of the above mentioned commission probably became the basis of an agreement concluded between the Gorzków parish priest and Jakub Sobieski, voivode of Ruthenia, and the owner of Chorupnik, at the meeting of the general chapter in Krasnystaw on $1^{\text {th }}$ January 1646, in which he undertook to build a new church and furnish it.

The third point of the agreement referred to the character of the church in Chorupnik: "Tertium punctum. This church of Chorupnik may not be taken to be a prebend or altaria, because ecclesiae parochiales in prebendas simplices cannot be converti, but as the former parochialis tenuior for the Gorzków parish it has adiungi et pro filia eidem haberi." ${ }^{24}$

The quoted fragment as well as the previous ones concerning the destruction of the church in Chorupnik and its incorporation indicate its rather special formal and legal status of a parish and subsidiary church. This is not a classic subsidiary church, often presented in opposition to a parish church. The affiliated status of a church would not necessarily mean the loss of parish rights, but it was due to its subordination to the principal parish. In the modern era, there were two types of parish churches: the principal church (ecclesia mater, principalis) and the subsidiary one (ecclesia subsidiary,

\footnotetext{
21 “ “...] quam ecclesiam neque ab illustrissimo palatino Russiae, necque ab eius parente, qui bona Chorupnik and iam desolatam ecclesiam a nobili Eustachio Romano acquisivit" (AAL, Rep60 A160, sheet 516v).

${ }^{22}$ Włodzimierz CZARNECKI, Szlachta ziemi chetmskiej do połowy XVI wieku (Białystok: Instytut Badań nad Dziedzictwem Kulturowym Europy, 2012), 219.

${ }^{23}$ Maria Sipayłło, editor, Małopolska 1571-1632 (Warszawa: Państwowe Wydawnictwo Naukowe, 1983), 72. Vol. 1 of Akta synodów różnowierczych w Polsce.

${ }^{24}$ AAL, Rep60 A154, sheet 556; AAL, Rep60 A160, sheets 497-499v, 516-517.
} 
accessoria). A church may have a subsidiary (auxiliary) character from the moment of its establishment or may have obtained such a status over time, e.g. as a result of being incorporated or joined to another parish. A separate parish district of the Chorupnik parish was still remembered at the beginning of the $19^{\text {th }}$ century. ${ }^{25}$

The agreement was concluded just before Jakub Sobieski's death in 1646 and before the havoc wreaked by the Cossack wars. In the light of the survey conducted so far, it is difficult to establish the exact relationship between the so-called cemetery commission and the agreement of early 1646 and the judgements of the land court and the Crown Tribunal of 1655. It can be assumed that there was constant judicial pressure from ecclesiastical institutions (the bishop, cathedral chapter, or parish priest) to force concessions and the return of the revenue of the parish of Chorupnik. This judicial pressure on Jakub Sobieski is, however, difficult to interpret, as we know of his foundations and financial support of the Church in other places. ${ }^{26}$ The settlement concluded on $1^{\text {th }}$ January 1646 between the Gorzków parish priest and Jakub Sobieski, attested in the files of the Crown Tribunal in 1655, indicates the desire to recover the largest possible share of the estate lost during the Reformation. The chapter extended the interpretation of particular points of the settlement, increasing the obligations of Jakub Sobieski. For example, the first point, concerning the erection of the church and the purchase of a bell, was supplemented by the chapter "with a proviso that a fence near the church be erected and by the church's bell made." The fourth point says: "Do tego iako jegomość pan wojewoda pozwala aby pułłanik ieden y zagrodnik, a venerabile capitulum rozumie żeby dwa zagrodniki do pułłanika temuż kościołowi," while the fifth point mentions that instead of the right of free logging "rozumie venerabile capitulum iż incysia w lasach nie potrzebna poniewasz las kościołowi ma być puszczony."27

\footnotetext{
25 "Villae autem Vishniov, Chorupnik, Borow et Borowek ad ecclesiam quondam Chorupnicensem pertinentes anno 1639 tam quoad curam animarum quam quoad perceptionem proventus et iurium vindicationem ecclesiae Gorzkoviensis subiectae patent" (AAL, Rep60 A191, sheet 30 ).

${ }^{26}$ Foundations of new parish churches in Złoczów, Zborów, Jezierna, Pomorzany, monastery and church of the Carmelite Order in Lviv, Jan DŁugosz, "Sobieski Jakub h. Janina," in Polski Stownik Biograficzny, vol. 39, 488.

${ }^{27}$ AAL, Rep60 A154, sheets 556-556v: "In addition, his Lordship the voivode, permits a pullanik [half a lan of land] and a zagrodnik [crofter, hortulanus], but the venerable chapter acknowledges that from two zagrodniks to one pullanik-" (Point 4) and "forest logging is not necessary because forest to that church shall be given" (Point 5).
} 
It can be concluded that Jakub Sobieski (despite the settlement) was not able to meet the demands of the ecclesiastical party, since the appeal procedure in the Crown Tribunal took place in the 1650s, when the heirs of Chorupnik were already represented by Jan Sobieski, the starost of Jaworów (the future king) and his mother, widow of Jakub Sobieski, Teofila of Żurów, née Daniłłowicz, and the parish priest of Gorzków Wawrzyniec Różniecki (Różnicki). We know of a copy of the document confirming and upholding the judgement of the Krasnystaw land court by the Crown Tribunal in Lublin, dated $18^{\text {th }}$ June 1655. It ordered the payment of 100 florins for each year of tithes overdue (since the death of the parish priest of Gorzków) and to return the grain collected from the fields of the Chorupnik church (or its equivalent). ${ }^{28}$

The settlement concluded between Jakub Sobieski and the parish priest on $1^{\text {th }}$ January 1646 , confirmed by the judgement of the Crown Tribunal on 18 June 1655, was never implemented. The church in Chorupnik was not rebuilt, and the efforts of the church authorities, the bishop, cathedral chapter and parish priest in Gorzków to maintain the parish in Chorupnik turned out to be ineffective. On $5^{\text {th }}$ May 1668, a final settlement was concluded between Jan Stefan Siestrzewitowski, parish priest of Gorzków and canon of Chełm, and Jan Sobieski of Złoczów and Żółkiew, marshal and Great Hetman of the Crown, in which Sobieski granted the parish priest of Gorzków his subjects and the land estate of the Chorupnik parish, which thus vanished. ${ }^{29}$

If we view the case of the church in Chorupnik against a wider social and religious background, it should be obvious that the way churches were recovered by the Latin Church in the late $16^{\text {th }}$ and early $17^{\text {th }}$ centuries is an interesting and complex issue but little analysed by the literature of the subject. This phenomenon should be viewed from a wider perspective of the attitude of the nobility towards the Catholic Church in this period. Considering the temporary takeover of a large part of the estates and Catholic churches, ${ }^{30}$ the relations between the nobility and the institutional Church in which the lack of mutual trust and conflicts began to dominate had to be completely

\footnotetext{
${ }^{28}$ AAL, Rep60 A154, sheet 553v-557v.

${ }^{29}$ AAL, Rep60 A153, sheet 511nn (6 sheets-an account of a visitation in 1711).

${ }^{30}$ Speaking of losses in the fabric of the Catholic Church, it is necessary to distinguish between temporary and permanent losses, see Stanisław LiTAK, "Kościół w Polsce w okresie reformacji i odnowy potrydenckiej," in Historia Kościoła 1500-1715, vol. 3, edited by Ludovicus Jacobus Rogier, Robert Aubert, David Knowles (Warszawa: Pax, 1986), 387; IDEM, Parafie w Rzeczypospolitej w XVI-XVIII wieku. Struktura, funkcje społeczno-religijne i edukacyjne (Lublin: Wydawnictwo KUL, 2004), 43-44.
} 
redefined. The interpretation of the nobility's return to Catholicism hinges on the reasons for its conversion to the reformed faiths and, indirectly, on the assessment of its religiousness during the Reformation period. The answer to the question about the intentions and motives of the conversion to Lutheranism or Calvinism with accompanying takeovers of Catholic churches and estates is still open. It is not even clear whether churches and estates were taken over due to a change of the confessed religion or whether conversions were the result of a desire to take over the estates of Catholic parishes. We observe the confrontation of two appraisals of the attitudes of the nobility, which can be described as "optimistic" and "pessimistic." An extremely pessimistic appraisal, not devoid of a religious bias, was presented by A. Wadowski in a study devoted to the diocese of Chełm (excerpts):

The Polish nobleman was religious in a way purely in the interests of his own, selfish views. He held on to the Catholic Church when, after a reform adopted without conviction and abandoned without regret, he moved back to her bosom; but also because that Church would not claim the possession of the robbed property [emphasis by B. Sz.], and allowed the remaining property to be used exclusively by his sons. - The nobility clung to it [the Reformation-B. Sz.] from the excess of freedom, from the desire to break away from the only shackles of the laws of the Church, from greed for the church property. Converting to the other faith, they felt released from excommunication or from tithing, empowered to occupy the church property lying within their estate or even churches themselves. So they seized, demolished and destroyed them, not building anything in their place. - The nobility, having ceased to be Protestant, did not cease to be insolent, reckless and selfish, and used these qualities not only in politics but also in religion. Such as the Grand Chancellor and Hetman of the Crown Jan Zamoyski, were not many among the nobility after returning to the bosom of the Church. For that reason, the attempts of several bishops to recover old foundations, namely Sobiejuski, Pilichowski, especially Gomoliński, Zamoyski, Łubieński and Koniecpolski, deserve eternal remembrance on account of difficulties in organizing the diocese of Chełm anew after its destruction by heresy. That they did not regain everything and that their successors could not hasten the issue of the church was no longer their guilt, but the guilt of the character of their adversaries, the union and the nobility - the former lacked sincerity, and the other lacked political aptitude. ${ }^{31}$

A more optimistic appraisal, which attributes deeper political motives related to socio-political reforms and the execution movement to the nobility supporting the Reformation, is noticeable in contemporary historiography. However, even these voices betray rather base motivation of the nobility,

\footnotetext{
${ }^{31}$ Jan Ambroży WADOwski, Dzieje dawnej diecezji chetmskiej, sheets 15v-18v.
} 
which was chiefly material and marked by opposition to the clergy. ${ }^{32}$ The complexity of these issues has recently been demonstrated by U. Augustyniak, who postulated the need to study the conflict between the nobility and clergy during the Reformation and Counter-Reformation at three basic levels: social, legal and economic. ${ }^{33}$

In the light of the above remarks, it can be assumed that an important reason for the so-called return of the nobility to the bosom of the Catholic Church in the last two decades of the $16^{\text {th }}$ century and in the first decades of the $17^{\text {th }}$ century was the growing pressure from the Catholic Church (especially its bishops), strongly supported by the royal court, mainly manifested by efforts to regain the seized churches and church estates. It should be remembered that the post-tridentine legislation provided for the loss of patrons' rights, including the right of presentation, on account of departure from the Catholic Church. Considering the support of the state authorities, in the case of lawsuits brought by bishops, chapters or parish priests, the owners of parish towns and villages were threatened with the loss of assets they had previously seized and the loss of impact they had on the staffing and thus on the management of the parish property. The nobility, coerced administratively and legally into returning the previously seized property, was inclined to enter into agreements and compromises, which to some extent satisfied the demands of the Church, but allowed them to keep at least some part of the seized church property. More extensive research based on court records, both ecclesiastical (consistory, bishop's acts) and civil (municipal and land records, Crown Tribunal), which would analyse the course and methods of property recovery by the Catholic Church in the first half of the $17^{\text {th }}$ century, are necessary to obtain a full picture of the Polish Reformation and Counter-Reformation.

\footnotetext{
32 "Meanwhile, the political involvement of the nobility intensified, whose important element were the demands of church reform, which stemmed mainly from their envy of the clergy's benefits, tithing, benefices, and tax exemptions" (Wojciech KRIEGSEISEN, Stosunki wyznaniowe w relacjach państwo-kościót między reformacja i oświeceniem (Warszawa: Wydawnictwo Naukowe Semper, 2010), 447). "One also gets the impression that the wealthy nobility-except for its narrow elite-who was accustomed to religious differences, supported the Reformation and frequently treated it as a kind of demonstration against the powerful ecclesiastical hierarchy, without a deeper knowledge of things and inner conviction" (Stanisław LITAK, Od reformacji do oświecenia. Kościót katolicki w Polsce nowożytnej (Lublin: Towarzystwo Naukowe KUL, 1994), 63).

${ }^{33}$ Urszula Augustyniak, Państwo świeckie czy księże? Spór o rolę duchowieństwa katolickiego w Rzeczypospolitej w czasach Zygmunta III Wazy. Wybór tekstów (Warszawa: Wydawnictwo Naukowe Semper, 2013), 9.
} 


\section{BIBLIOGRAPHY}

Augustyniak, Urszula, editor. Państwo świeckie czy księże? Spór o role duchowieństwa katolickiego w Rzeczypospolitej w czasach Zygmunta III Wazy. Wybór tekstów [A secular or a priestly state? Dispute over the role of the Catholic clergy in the Polish Republic of Sigismund III Vasa. A selection of texts]. Warszawa: Wydawnictwo Naukowe Semper, 2013.

BĄCZKowicz, Franciszek. Prawo kanoniczne. Podręcznik dla duchowieństwa [Canon law. A handbook for the clergy], vol. 1. Opole: Wydawnictwo Diecezjalne św. Krzyża, $1957^{3}$.

BIEŃKOwSKI, Ludomir. "Działalność organizacyjna biskupa Jana Biskupca w diecezji chełmskiej (1417-1452) [The organisational activity of bishop Jan Biskupiec in the diocese of Chełm (1417-1452)]." Roczniki Humanistyczne 7, no. 2 (1958): 187-256.

CZARNECKI, Włodzimierz. "Rozwój sieci parafialnej Kościoła łacińskiego w ziemi chełmskiej do początku XVII wieku [The development of the network of Latin Church parishes in Chełm land until the early $17^{\text {th }}$ century]." Roczniki Humanistyczne 48, no. 2 (2000): 29-89.

CZARNECKI, Włodzimierz. Szlachta ziemi chetmskiej do połowy XVI wieku [The nobility in Chełm land until the middle of the $16^{\text {th }}$ century]. Białystok: Instytut Badań nad Dziedzictwem Kulturowym Europy, 2012.

DŁugosz, Jan. “Sobieski Jakub h. Janina.” In Polski Stownik Biograficzny, vol. 39, 483-90.

FERRARIs, Lucius. Prompta bibliotheca canonica, iuridica, moralis, theologica, nec non ascetica, polemica, rubricistica, historica, vol. 9. Venetiis, 1782.

FoESSER, Justus Richard. De unione, speciatim de incorporatione beneficiorum. Moguntiae, 1869.

GMITEReK, Henryk. "Sobieski Marek h. Janina." In Polski Stownik Biograficzny, vol. 39, 502-504.

KRIEGSEISEN, Wojciech. Stosunki wyznaniowe $w$ relacjach państwo-kościót między reformacja $i$ oświeceniem [Religious relations between State and the Church during the Reformation and Enlightenment]. Warszawa: Wydawnictwo Naukowe Semper, 2010.

LiTAK, Stanisław. "Kościół w Polsce w okresie reformacji i odnowy potrydenckiej [The Church in Poland in the period of the Reformation and post-tridentine renewal]." In Historia Kościota 1500-1715, vol. 3, edited by Ludovicus Jacobus Rogier, Roger Aubert, and David Knowles, 343-416. Warszawa: PAX, 1986.

LITAK, Stanisław. Parafie w Rzeczypospolitej w XVI-XVIII wieku. Struktura, funkcje spotecznoreligijne i edukacyjne [Parishes of the Polish Republic in the $16^{\text {th }}-18^{\text {th }}$ centuries. The structure, social-religious and educational functions]. Lublin: Wydawnictwo KUL, 2004.

LiTAK, Stanisław. Od reformacji do oświecenia. Kościół katolicki w Polsce nowożytnej [From Reformation to Enlightenment. The Catholic Church in Poland of the modern era]. Lublin: Towarzystwo Naukowe KUL, 1994.

SZADY, Bogumił. "Inkorporacja parafii w Grabowcu do chełmskiej kapituły katedralnej w 1624 roku [The incorporation of the Grabowiec parish into the Chełm cathedral chapter in 1624]." In Kościót. Społeczeństwo. Kultura. Prace ofiarowane Profesorowi Wiestawowi Müllerowi zokazji pięćdziesięciolecia pracy naukowej i dydaktycznej [The Church. Society. Culture. Works dedicated to Professor Wiesław Müller for the $50^{\text {th }}$ anniversary of his scientific and didactic work], edited by Janusz Drob et al., 133-45. Lublin: Werset, 2004.

WAdowski, Jan Ambroży. Dzieje dawnej diecezji chetmskiej i jej kościołów [The history of the former diocese of Chełm and its churches], BPANKr, MS no. 2372. 


\title{
THE FALL OF THE CHORUPNIK PARISH A CONTRIBUTION TO THE HISTORY OF THE REFORMATION IN POLAND
}

\author{
Summary
}

The article addresses the question of the fall of the Latin parish in Chorupnik that belonged to the former diocese of Chełm. The parish church in Chorupnik was taken over by Protestants in the second half of the 16th century. Unsuccessful attempts at recovering its property were made by incorporating it into the neighbouring parish in Gorzków. The actions taken by the Gorzków parish priest and the bishop together with his chapter failed, too. A detailed study of such attempts to recover the property of one of the parishes that ceased to exist during the Reformation falls within the context of the relations between the nobility and the clergy in the period of Counter-Reformation. Studying the social, legal and economic relations in a local dimension is important for understanding the mechanisms of the mass transition of the nobility to reformed denominations, and then of their return to the Catholic Church.

Key words: Chełm Diocese; Chorupnik; Reformation; Counter-Reformation; Catholic clergy; Church benefices; nobility.

Translated by Tomasz Pałkowski

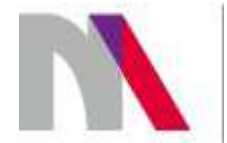

The preparation of the English version of Roczniki Humanistyczne (Annals of Arts) and its publication in electronic databases was financed under contract no. 836/P-DUN/2018 from the resources of the Minister of Science and Higher Education for the popularization of science. 